Kredo 3 (2020)
KREDO: Jurnal Ilmiah Bahasa dan Sastra
Terakreditasi Sinta 4 berdasarkan Keputusan Direktorat
Jenderal Penguatan Riset dan Pengembangan,
Kementerian Riset, Teknologi dan Pendidikan Tinggi
Republik Indonesia
Nomor: 23/E/KPT/2019. 08 Agustus 2019
https://jurnal.umk.ac.id/index.php/kredo/index

\title{
PENINGKATAN MINAT DAN HASIL BELAJAR KETERAMPILAN BERBICARA MENGGUNAKAN METODE MIND MAP PADA MAHASISWA KELAS IA PBSI IKIP PGRI BOJONEGORO TAHUN AKADEMIK 2019/2020
}

\author{
Agus Darmuki ${ }^{1}$, Ahmad Hariyadi ${ }^{2}$, Nur Alfin Hidayati ${ }^{3}$ \\ Agus_darmuki@yahoo.co.id ${ }^{1}$, ahmadhariyadi86@gmail.com ${ }^{2}$, Nikidanajwasalsabila@gmail.com ${ }^{3}$ \\ Prodi Pendidikan Bahasa dan Sastra Indonesia, Fakultas Pendidikan Bahasa dan Seni ${ }^{1,3}$ \\ Prodi Pendidikan Kewarganegaraan Fakultas Pendidikan \& Ilmu Pengetahuan Sosial ${ }^{2}$ \\ IKIP PGRI Bojonegoro, Indonesia
}

Info Artikel
Sejarah Artikel
Diterima 6 April
2020
Disetujui 7 Mei 2020
Dipublikasikan 20
Mei 2020
Keywords
interest, learning
outcome,
speaking, method,
mind map
Kata Kunci
minat, hasil
belajar, berbicara,
metode, mind
map

Info Artikel :

This research aims to increase the interest and learning outcomes of speaking skills in IA class students of PBSI IKIP IKRI PGRI Bojonegoro Academic Year 2019/2020. This class action research uses 2 cycles, each cycle consisting of planning, implementation, observation, and reflection. This research was conducted in the IA class of PBSI IKIP IKIP PGRI Bojonegoro Academic Year 2019/2020 odd semester with a total of 30 students with details of 8 male and 22 female, aged between 17-24 years. The data collection techniques of this study used questionnaires, observations, interviews and documentation. The results of the questionnaire in cycle 1 amounted to $60 \%$, an increase in interest in learning to speak increased in cycle 2, namely 96.7\%. Student learning outcomes average pre-cycle knowledge value of 65.4, cycle 1 an average - value of 72, 7, and cycle 2 77.0. While the average value of the skills value is 69.0 in the pre-cycle stage, 76.2 in cycle 1 and 78.0 in cycle 2. The conclusion of this study mind map method applied can increase the interest and learning outcomes of speaking skills in IA class students PBSI IKIP PGRI Bojonegoro Study Program Academic Year 2019/2020.

\section{Abstrak}

Penelitian ini bertujuan untuk meningkatkan minat dan hasil belajar keterampilan berbicara pada mahasiswa kelas IA Prodi PBSI IKIP PGRI Bojonegoro Tahun Akademik 2019/2020. Penelitian tindakan kelas ini menggunakan 2 siklus, masing-masing siklus terdiri dari perencanaan, pelaksanaan, pengamatan, dan refleksi . Penelitian ini dilaksanakan di kelas IA Prodi PBSI IKIP PGRI Bojonegoro Tahun Akademik 2019/2020 semester gasal dengan jumlah mahasiswa 30 orang dengan rincian 8 laki-laki dan 22 perempuan, usia antara 17-24 Tahun. Teknik pengumpulan data penelitian ini menggunakan angket, observasi, wawancara dan dokumentasi.. Hasil angket pada siklus 1 sejumlah 60\% peningkatan minat terhadap pembelajaran berbicara mengalami kenaikan pada siklus 2 yaitu 96,7\%. Hasil belajar mahasiswa rata-rata nilai pengetahuan pra siklus sebesar 65,4 , siklus 1 rata-rata nilai 72, 7, dan siklus 277,0 . Sedangkan nilai rata-rata nilai keterampilan yaitu 69,0 pada tahap pra siklus, 76,2 pada siklus 1 dan 78,0 pada siklus 2. Simpulan penelitian ini metode mind map yang diterapkan dapat meningkatkan minat dan hasil belajar keterampilan berbicara pada mahasiswa kelas IA Prodi PBSI IKIP PGRI Bojonegoro Tahun Akademik 2019/2020. 


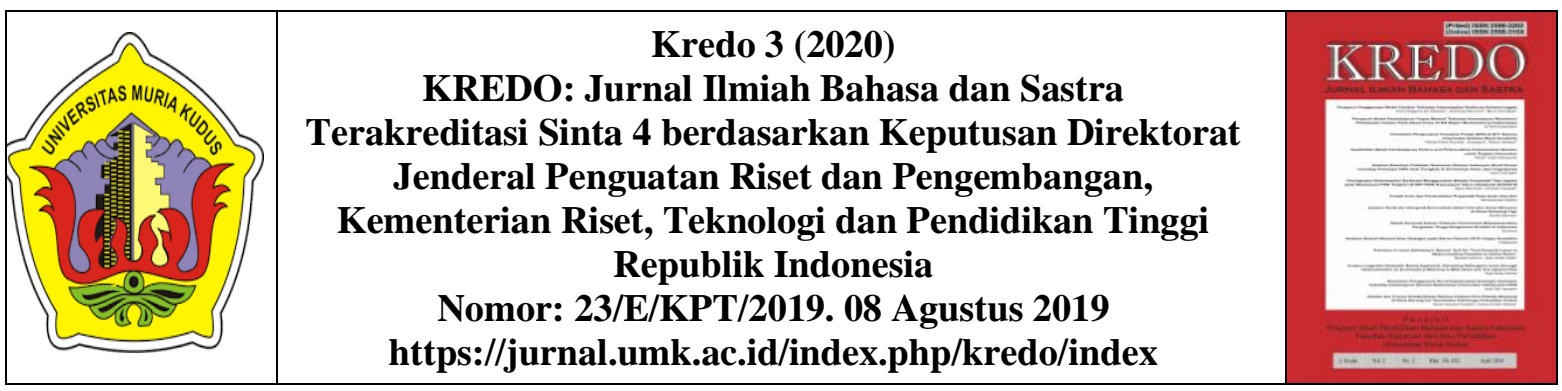

\section{PENDAHULUAN}

Belajar merupakan suatu proses perubahan tingkah laku yang membutuhkan minat untuk menggerakkan ke arah lebih baik, dari tidak bisa menjadi bisa, dari tidak tahu menjadi tahu (Darmuki et.al., 2017:45). Adanya minat belajar mahasiswa merupakan suatu hal yang sangat penting atau dominan dalam keberhasilan pendidikan khususnya pembelajaran di kelas. Untuk meningkatkan minat belajar mahasiswa maka diperlukan kreatifitas yang berkaitan dengan pembelajaran. Dengan meningkatnya minat mahasiswa dalam belajar maka secara signifikan prestasi hasil belajarpun secara otomatis akan meningkat pula (Hariyadi \& Darmuki, 2019:281). Minat merupakan faktor yang sangat penting dalam pembelajaran dan ditumbuhkan oleh dosen untuk memaksimalkan hasil belajar lebih baik. Minat belajar mahasiswa tentu burhubungan langsung dengan menarik/membosankan tidaknya pembelajaran di kelas.

Mata kuliah Keterampilan Berbicara di Prodi PBSI merupakan mata kuliah yang sangat penting dikuasai oleh mahasiswa untuk melatih kemampuan alur berpikir mahasiswa dalam menyampaikan ide gagasan, pikiran, dan informasi kepada orang lain (Darmuki et.al., 2018: 115 ). Alur berpikir mahasiswa dalam menyampaikan ide atau pikiran kepada orang lain akan menunjukkan kemampuan intelektual/pengetahuan mahasiswa. Keterampilan berbicara sangat dibutuhkan dalam kehidupan sehari-hari manusia terutama dalam berinteraksi antara seseorang dengan orang lain untuk menyampaikan pesan atau informasi (Darmuki \& Hidayati,
2019:9). Mata kuliah keterampilan berbicara bertujuan agar mahasiswa mampu berkomunikasi dengan lancar dan pesan yang disampaikan bisa diterima lawan bicaranya dengan baik, sehingga melatih daya berpikir mahasiswa menjadi runtut dan logis dalam hal berkomunikasi. Hal inilah yang menjadikan pentingnya penguasaan tersebut untuk dilatih terus menerus hingga tujuan pembelajaran tercapai. Pentingnya penguasaan keterampilan berbicara tersebut menjadikan perhatian dosen lebih dibandingkan keterampilan yang lain (Darmuki \& Hidayati, 2019:122). Selama ini materi tersebut belum dikuasai seutuhnya oleh mahasiswa dengan berbagai alasan. Mulai kesulitan berbicara secara runtut, kesulitan mengatur alur berbicara dengan runtut, sampai kesulitan dalam hal menyusun kata-kata yang baik dalam bentuk lisan.

Berdasarkan observasi awal kesulitan mahasiswa di dalam penguasaan keterampilan berbicara tidak terlepas dari proses pembelajaran yang telah dilakukan dosen selama ini. Dosen masih cenderung menggunakan metode yang kurang tepat di dalam mengajarkan keterampilan berbicara tanpa melihat permasalahan mahasiswa di lapangan. Pemilihan metode pembelajaran yang dilakukan dosen belum memperhatikan karakteristik mahasiswa yang ada di kelas. Dosen hanya melakukan analisa pemilihan metode berdasarkan ketercapaian tujuan pembelajaran saja dan mengabaikan karakteristik mahasiswa nyata di kelas. Hal ini terlihat ketika wawancara awal dengan dosen di ruang kerja salah satu dosen bahwa RPS dosen dibuat sama dengan tahun yang lalu, padahal dosen tahu bahwa mahasiswa yang dihadapi pada semester 


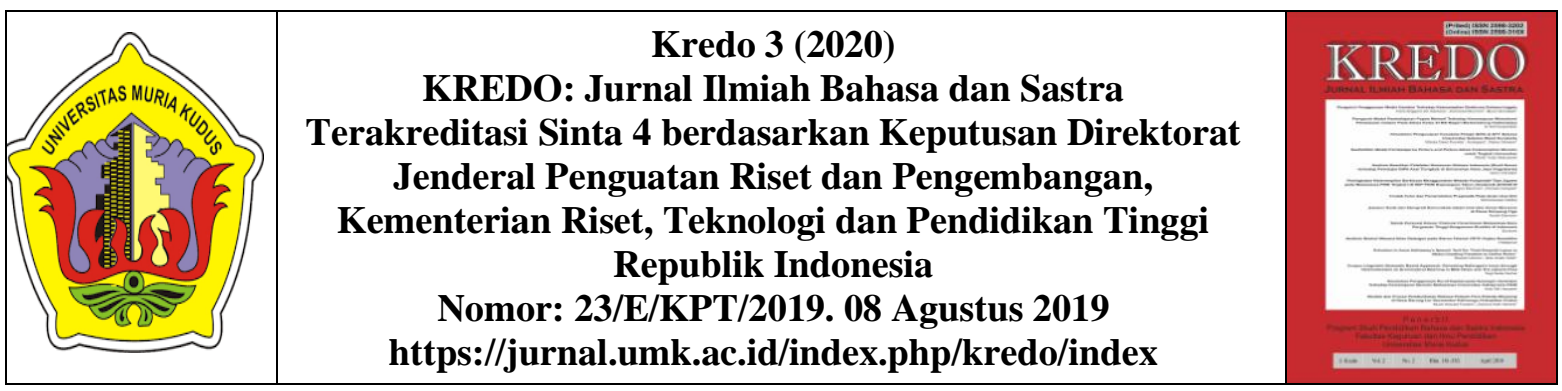

ini berbeda dengan semester satu tahun yang lalu.

Wawancara awal dengan mahasiswa juga ditemukan bahwa mahasiswa kurang berminat dengan mata kuliah Keterampilan Berbicara karena kurang menarik pembelajarannya di kelas. Selain itu mahasiswa merasa masih kesulitan berbicara yang runtut, logis dan lancar ketika tampil menyampaikan ide, gagasan, pikiran, dan informasi kepada orang lain. Mahasiswa kesulitan berbicara karena keterbatasan aspek pengetahuan mengenai topik yang akan disampaikan ketika berbicara di depan umum. Selain itu, aspek keterampilan berbicara mahasiswa juga masih rendah hal ini terlihat ketika diwawancarai oleh peneliti menjawab pertanyaan peneliti belum lancar dan masih belum runtut berbicaranya.

Berbicara adalah salah satu cara berkomunikasi antar manusia. Di dalam komunikasi, bahasa berperan penting dalam mencapai tujuan. Kejelasan berbicara akan memperjelas maksud ucapan seseorang sehingga mengurangi kesalahan dalam mengartikan/memahaminya. Sebagai salah satu keterampilan berbahasa dalam pembelajarannya pasti ditemukan berbagai persoalan yang harus diatasi. Salah satu persoalan yang sering muncul dalam pembelajaran keterampilan berbicara adalah minat dan kemampuan berbicara yang kurang baik atau keruntutan berbicara. Kemampuan yang kurang tersebut juga tidak terlepas dari penggunaan metode pembelajaran yang dipakai dosen di kelas. Kemampuan mengelola kelas dan penggunaan metode pembelajaran menjadi salah satu yang mengakibatkan minat dan kemampuan berbicara mahasiswa masih rendah. Pemilihan metode pembelajaran menjadi salah satu hal yang penting untuk dipertimbangkan dosen ketika mengajar di kelas. Pemilihan metode pembelajaran yang kurang tepat akan berdampak pada proses pembelajaran itu sendiri.

Salah satu cara agar terampil berbicara dengan baik adalah dengan mempersiapkan alur berpikir dan penguasaan konsep, berlatih menirukannya, lalu mempraktikkannya. Dengan menirukan ucapan (bunyi) dan mempraktikkannya, mahasiswa akan belajar mengucapkan kata dengan intonasi, dialek, dan nada suara sesuai dengan alur berpikir dan konsep yang sudah disiapkan. Metode mind map akan membantu mahasiswa untuk berbicara menggunakan alur berpikir logis dan penguasaan konsep (Adeneye,2011; Ajaja, 2011; Akeju, 2012; Alireza et.al., 2012; Bamidele \& Oloyede, 2013; Barchok et.al, 2013). Pemetaan konsep adalah ide sentral atau konsep yang terpancar keluar dalam ide-ide terkait. Peta konsep juga disebut peta mental, peta pikiran, cluster, pemetaan, kata webbing, alur berpikir atau cabang ide (Lim, Cheng, Lam, \& Ngan 2003: 55; Peterson \& Snyder 1998: 6).

Metode mind map mengondisikan mahasiswa menyiapkan topik/bahan isi yang disampaikan, penggunaan lafal, intonasi, diksi dan kelancaran berbicara. Berdasarkan permasalahan di atas maka dosen harus melakukan perbaikan pembelajaran dengan menetapkan penggunaan metode mind map pada mahasiswa kelas IA Prodi PBSI IKIP PGRI Bojonegoro.

\section{KAJIAN TEORI}

Menurut Hamdani (2011:23) pembelajaran adalah usaha yang dilakukan dosen membentuk tingkah 


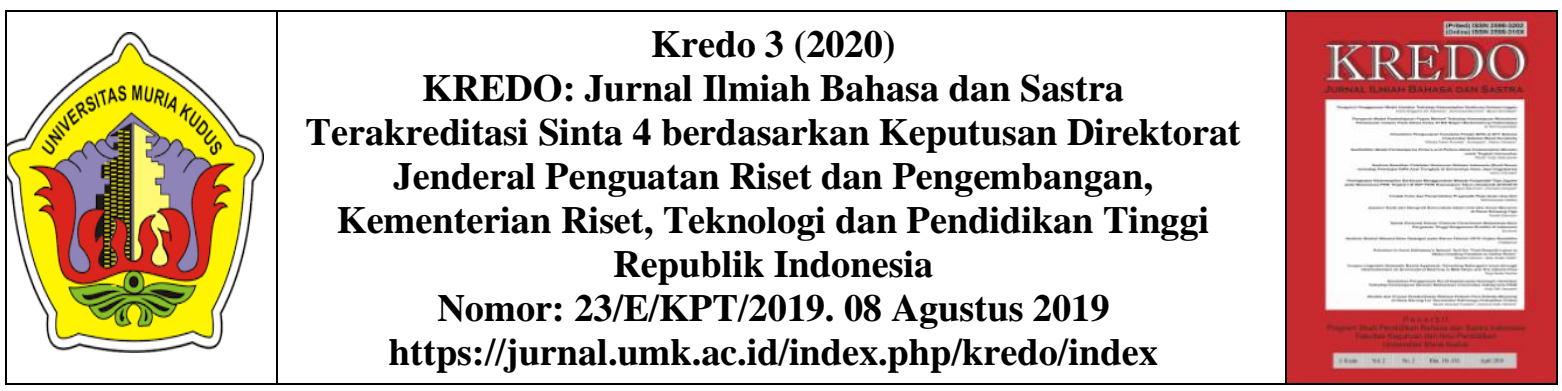

laku peserta didik yang diinginkan sesuai tujuan pembelajaran dengan menyediakan lingkungan belajar atau stimulus. Selanjutnya menurut Gagne et.al (2008: 266) bahwa pembelajaran adalah suatu sistem yang bertujuan untuk membantu proses belajar peserta didik, yang berisi serangkaian peristiwa yang dirancang, disusun sedemikian rupa untuk mempengaruhi dan mendukung terjadinya proses belajar peserta didik yang bersifat internal. Perancangan pembelajaran ini berkaitan dengan penggunaan metode pembelajaran untuk membelajarkan mahasiswa di kelas. Pemilihan metode pembelajaran atau strategi pembelajaran harus memperhatikan aspek menumbuhkan minat pembelajaran dan juga pemahaman/pengetahuan serta aspek penguasaan keterampilan mahasiswa (Eggen \& Kauchak, 2012: 3).

Metode pembelajaran merupakan suatu proses penyampaian materi pendidikan kepada peserta didik yang dilakukan secara sistematis dan teratur oleh tenaga pengajar atau pendidik (Sudjana, 2005:76). Pendapat lain mengatakan, metode pembelajaran adalah suatu strategi atau taktik dalam melaksanakan kegiatan belajar dan mengajar di kelas yang diaplikasikan oleh tenaga pengajar sehingga tujuan pembelajaran yang telah ditetapkan dapat tercapai dengan baik. Seorang dosen harus bisa menerapkan metode yang tepat dalam kegiatan belajarmengajar, sesuai dengan karakter para mahasiswanya. Selain itu, dosen dalam memilih metode pembelajaran perlu memperhatikan tujuan pembelajaran, karakteristik mahasiswa, karakteristik materi, kemampuan dosen sendiri, dan ketersediaan fasilitas dan sarana prasaran pembelajaran (Darmuki dan Hidayati,
2019:9). Dengan begitu, proses belajarmengajar menjadi lebih menyenangkan dan mahasiswa dapat menyerap pelajaran dengan lebih mudah.

Menurut Winkel (1996:24) minat adalah "kecenderungan yang kuat menetap pada perasaan tertarik dengan suatu bidang tertentu dan merasa senang dalam menjalaninya. Kecenderungan yang tinggi dan menetap ini dimiliki sebagai sarana untuk memperhatikan suatu kegiatan yang dimiliki oleh seseorang yang secara terus menerus diperhatikan dengan rasa sayang. Minat juga merupakan sebuah pemusatan perhatian pada kemauan dari bakat yang dimilikinya (Hariyadi \& Darmuki, 2019: 281). Minat adalah suatu dorongan yang terjadi secara sugestif untuk melakukan sesuatu pada diri seseorang yang membutuhkan adanya stimulus/rangsangan sebagai akibat dari tindakan seseorang baik positif maupun negatif (Darmuki et.al., 2017:76).

Pengertian mind map Menurut Liu (2011:25-54) adalah adanya hubungan saling keterkaitan antara konsep dan prinsip yang ditampilkan seperti jejaring konsep yang perlu dikonstruksikan, jejaring konsep yang telah dikonstruksikan inilah yang disebut sebagai mind map. Sutanto (2008:9) juga mengatakan bahwa mind map merupakan suatu bagian skematik yang menggambarkan suatu konseptual seseorang dalam dalam sebuah pernyataanMind map fokus pada satu titik kemudian memiliki hubungan saling keterkaitan dengan yang lainnya.Ada dua prinsip yang digunakan untuk saling menghubungkan konsep tersebut yaitu prinsip diferensial progresif dan prinsip penyesuaian integratif. Mind map memiliki ciri ciri seperti yang telah disampaikan oleh Şeyihoğlu \& Geçit 


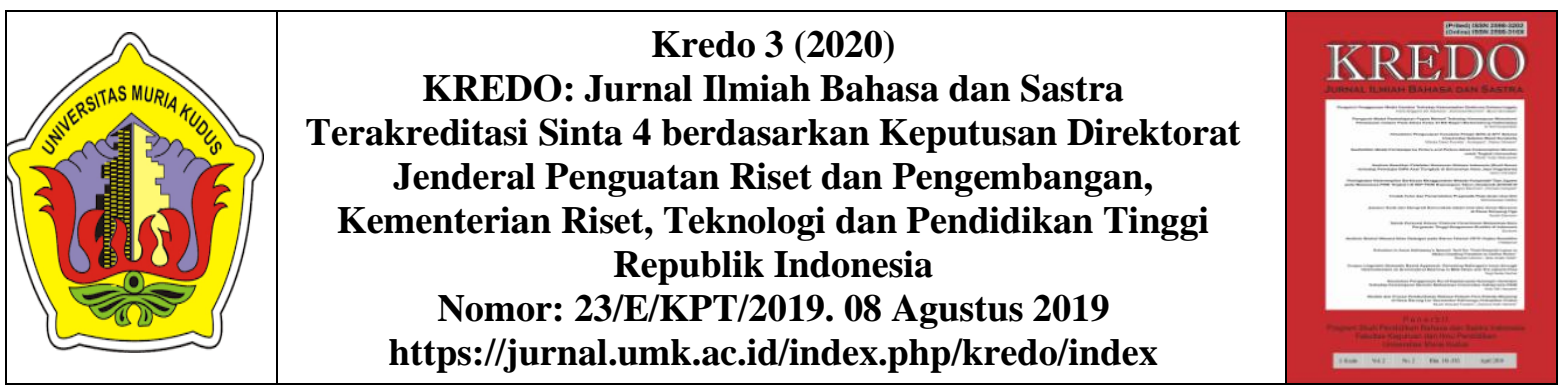

(2012:284) diantaranya sebagai berikut: (1) Mind map menggambarkan konsep konsep yang proposisi dalam suatu topik bidang studi; (2) di dalam mind map terdapat hubungan keterkaitan antara konsep konsep tersebut; (3) apabila konsep konsep tersebut telah dihubungkan maka terbentuklah suatu hirarki pada peta konsep itu. Edward (2009: 12) Mind map merupakan ide atau gagasan-gagasan dalam rencana pembelajaran yang dapat digunakan sebagai petunjuk oleh dosen (Sutarni, 2011:27). Sedangkan menurut Arends (2008:12) Mind map menyajikan cara yang baik bagi mahasiswa untuk bisa memahami beberapa informasi baru. Siswa lebih mudah mengingat karena bentuknya yang berupa konsep.

Mind map dapat digambarkan sebagai cara visual mewakili pengetahuan di mana ada hubungan konsep dan proposisi (Chularut \& DeBacker, 2004: 249 ). Mind map merupakan alat konsep yang digunakan untuk mengatur dan mewakili pengetahuan (Marriott \& Torres, 2008:9). Melalui metode pembelajaran mind map peserta didik mampu mengeksternalisasi pengetahuan mereka yang ada dan menggabungkannya dengan pengetahuan yang baru (Cicognani, 2000: 151). Metode mind map dapat memberikan ruang kepada peserta didik menata ulang dan menginternalisasi baik pengetahuan yang lama dan pengetahuan baru dalam bentuk alur berpikir (Fahim \& Heidari, 2006:121). Fitur yang utama mind map adalah struktur hierarkisnya yang mengidentifikasi konsep tertentu, biasanya konsep-konsep yang menunjukkan bagaimana pengetahuan tertentu konsep atau domain terkait dengan konsep atau domain lain (Hsu \&
Chang, 2009: 15). Pembelajaran min map menekankan dari konsep yang paling umum dan inklusif ditempatkan di bagian atas peta, sedangkan konsep khusus ditempatkan di bawah secara bertingkat berhubungan antara konsep yang satu dengan lainnya (Kostovich et.al., 2007: 218). Mind map dapat mengontruksi kognitif yang divisualisasikan menjadi konsep alur yang runtut (Yen et.al., 2012: 308). Menurut Stoica dkk. (2011: 568) tentang mind map menunjukkan bagaimana peta konsep dapat digunakan untuk menunjukkan berbagai hubungan antar konsep.

Sebagaimana diungkapkan DePorter, dan Hernacki (2001: 54) bahwa untuk bisa membantu kita dalam mengingat bacaan dan perkataan serta untuk meningkatkan suatu pemahaman terhadap materi, maka diperlukan metode mencatat agar dapat mengorganisasi materi dengan baik dan memberikan wawasan yang baru. Peta konsep dikembangkan Buzan dan Buzan (1996) pada tahun 1970-an merupakan suatu teknik dalam memetakan konsep atau teknik mencatat informasi yang sesuai dengan bagaimana cara otak bisa bersinergi dan berfungsi antara otak kanan dan otak kiri secara bersama-sama dan saling melengkapi (DePorter dan Hernacki, 2001:22; Hay, 2008:1057). Radix dan Abdool (2013:4) mengatakan ketika kita membutuhkan struktur pada saat perkuliahan bisa membuat ringkasan dengan teknik mind map untuk melatih keterampilan berbicara. Metode mind map akan membantu mahasiswa menuangkan alur berbicaranya dengan terlebih dahulu mencatatnya sehingga dapat mengorganisasi materi berbicaranya lebih runtut dan logis. 


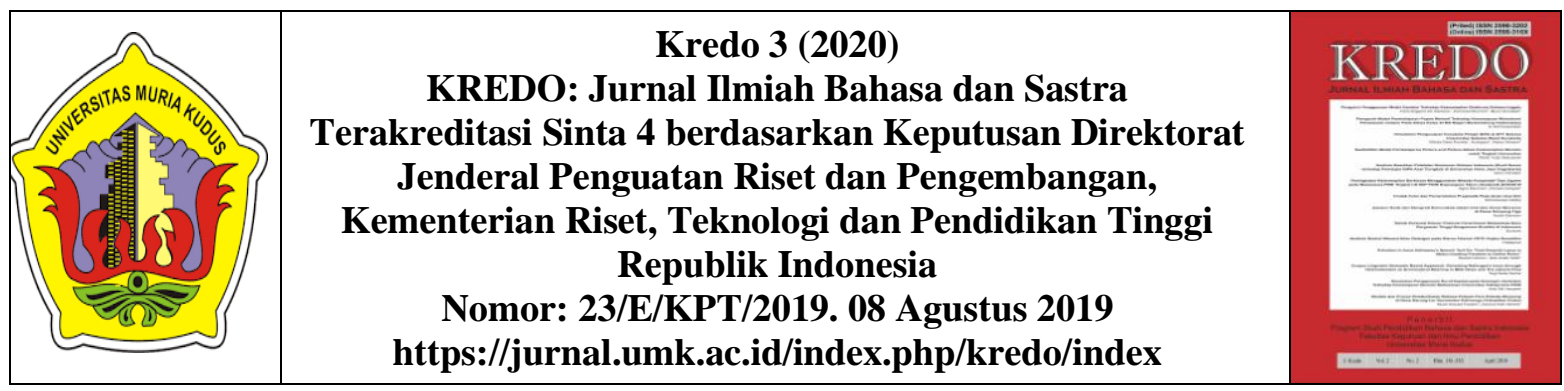

Hasil belajar adalah perubahan perilaku dan kemampuan secara keseluruhan yang dimiliki oleh mahasiswa setelah belajar, yang wujudnya berupa kemampuan kognitif, afektif, dan psikomotor (bukan hanya salah satu aspek potensi saja) yang disebabkan oleh pengalaman (Darmuki \& Hariyadi, 2019: 63). Hasil belajar mahasiswa tidak hanya menekankan penguasaan pengetahuan saja tetapi juga penguasaan keterampilan yang nantinya akan berdampak pada perubahan perilaku/sikap mahasiswa. Penguasaan tersebut tentunya harus melalui proses belajar terus-menerus dan melalui pengalaman belajar baik teoritis maupun praktis.

\section{METODE PENELITIAN}

Penelitian ini merupakan jenis penelitian tindakan kelas dengan pendekatan deskriptif kualitatif. Penelitian tindakan kelas ini menggunakan 2 siklus, masing-masing siklus terdiri dari perencanaan, pelaksanaan, pengamatan, dan refleksi. Penelitian ini dilaksanakan di kelas IA Prodi PBSI IKIP PGRI Bojonegoro Tahun Akademik 2019/2020 semester gasal dengan jumlah mahasiswa 30 orang yang terdiri dari 8 laki-laki dan 22 perempuan, usia antara 17-24 Tahun. Sumber data penelitian ini berupa proses pembelajaran mata kuliah keterampilan berbicara dengan satu orang dosen pengampu mata kuliah Keterampilan Berbicara di Prodi PBSI IKIP PGRI Bojonegoro. Data penelitian ini berupa proses pembelajaran mata kuliah Keterampilan Berbicara di kelas IA Prodi PBSI IKIP PGRI Bojonegoro. Teknik pengumpulan data penelitian ini menggunakan angket, observasi , wawancara dan dokumentasi.

Teknik pengumpulan data menggunakan observasi digunakan untuk mengumpulkan data mengenai proses pembelajaran di kelas selama observasi awal, siklus 1 maupun siklus 2. Observasi menggunakan lembar observasi mahasiswa dan lembar observasi dosen dalam proses pembelajaran. Wawancara digunakan untuk mengetahui tanggapan dosen mengenai penggunaan metode pembelajaran awal wawancara, selama siklus 1 maupun siklus 2. Wawancara menggunakan panduan wawancara yang sudah disiapkan secara terstruktur. Angket digunakan untuk mengumpulkan data respon mahasiswa terhadap minat mahasiswa dalam pembelajaran mata kuliah Keterampilan Berbicara pada saat awal, siklus 1 maupun siklus 2. Teknik pengumpulan data penelitian ini menggunakan dokumentasi, yang digunakan untuk mengumpulkan informasi berupa dokumen terkait dengan penelitian yang dilakukan. Evaluasi pembelajaran keterampilan berbicara menggunakan tes berupa unjuk kerja yang dilengkapi dengan lembar observasi (Hughes, 2003: 58). Observasi terhadap mahasiswa dilakukan untuk menilai praktik berbicara mahasiswa saat tampil di depan kelas.

\section{HASIL DAN PEMBAHASAN}

Peneliti menyebar angket awal sebelum pelaksanaan siklus 1, untuk mengetahui kondisi awal proses pembelajaran di kelas. Dari kegiatan survei awal, peneliti menemukan bahwa minat pembelajaran keterampilan berbicara mahasiswa masih tergolong rendah. Hal ini disebabkan salah satunya 


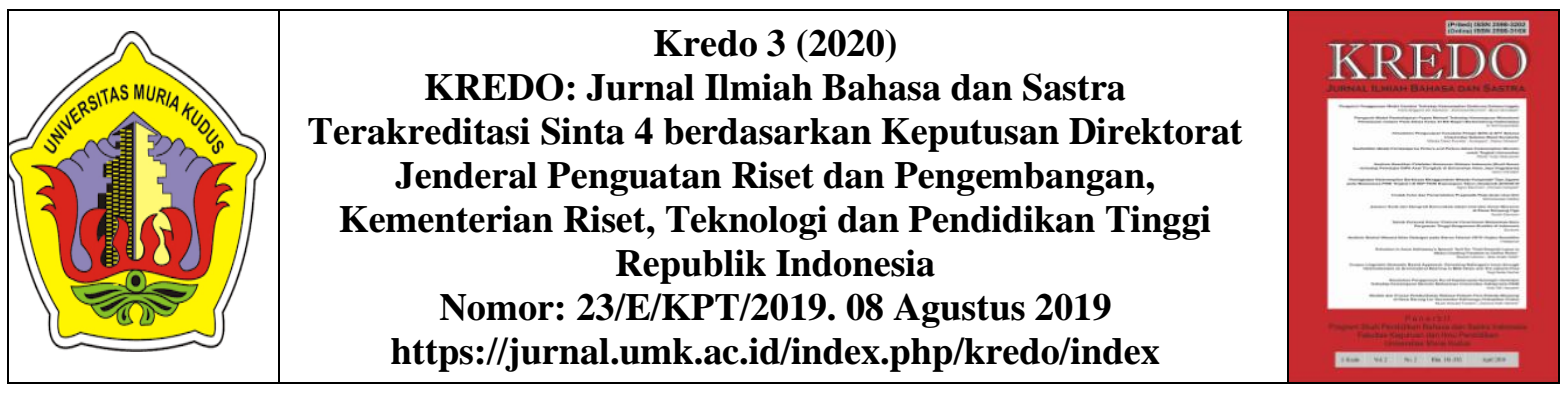

penggunaan metode pembelajaran dosen kurang menarik dan menyenangkan. Selain itu pembelajaran yang dilakukan dosen masih bersifat konvensional dan membuat pembelajaran membosankan sehingga mahasiswa kurang berminat. Metode pembelajaran yang digunakan dosen tidak memberikan motivasi kepada mahasiswa untuk mau belajar berbicara. Mahasiswa tidak tertarik dengan pembelajaran keterampilan berbicara, diperparah dengan persepsi mahasiswa yang menganggap keterampilan berbicara tidak terlalu penting manfaatnya dalam kehidupan sehari-hari.

Oleh karena itu, peneliti bersama dosen melakukan kolaborasi penelitian perbaikan pembelajaran dengan menggunakan metode mind map. Perencanaan perbaikan pembelajaran di desain melalui tindakan siklus 1 dan siklus 2 yang masing-masing terdiri dari perencanaan, pelaksanaan, pengamatan (observasi), dan refleksi. Perbaikan pembelajaran pada tindakan siklus 1 dan siklus 2 dengan membagikan angket untuk mengetahui minat mahasiswa dalam pembelajaran setelah menggunakan metode mind map. Berdasarkan hasil skor angket minat pelaksanaan tindakan pada siklus 1 dan siklus 2 dapat dinyatakan bahwa terjadi peningkatan minat pembelajaran berbicara dengan metode mind map. Hal tersebut dapat dilihat bahwa minat mahasiswa dalam mengikuti pembelajaran berbicara meningkat. Peningkatan pembelajaran berbicara pada tindakan siklus 1 sebanyak $60 \%$ (18 orang) dan pada tindakan siklus 2 meningkat menjadi $96,7 \%$ (29 orang). Peningkatan minat pembelajaran keterampilan berbicara tersebut dapat dilihat pada tabel di bawah ini.
Tabel 1. Perbandingan Minat Skor PraSiklus, Siklus 1, Siklus 2

\begin{tabular}{|c|c|c|c|c|}
\hline $\begin{array}{l}\text { Skor } \\
\text { Angket }\end{array}$ & Kategori & $\begin{array}{c}\text { Pra } \\
\text { Siklus }\end{array}$ & $\begin{array}{c}\text { Siklus } \\
1\end{array}$ & $\begin{array}{c}\text { Siklus } \\
2\end{array}$ \\
\hline $85-100$ & Sangat baik & 0 & 0 & 7 \\
\hline $70-84$ & Baik & 4 & 18 & 22 \\
\hline $50-69$ & Cukup & 16 & 10 & 1 \\
\hline $35-49$ & Kurang & 10 & 2 & 0 \\
\hline$>35$ & $\begin{array}{l}\text { Sangat } \\
\text { Kurang }\end{array}$ & 0 & 0 & 0 \\
\hline
\end{tabular}

Berdasarkan tabel di atas bahwa minat mahasiswa terhadap pembelajaran keterampilan berbicara pada pra-siklus kategori kurang baik ada 10 orang, 16 orang kategori cukup baik, 4 orang kategori baik, dan nol kategori sangat baik. Hasil angket siklus 1 menunjukkan adanya kenaikan dengan rincian 2 orang kategori kurang baik, 10 orang ketegori cukup baik, 18 orang kategori baik, dan nol kategori sangat baik. Sedangkan minat mahasiswa terhadap pembelajaran keterampilan berbicara pada siklus 2 kategori kurang baik nol, 1 orang kategori cukup baik, 22 orang kategori baik, dan 7 orang kategori minatnya sangat baik. Minat mahasiswa terhadap pembelajaran keterampilan berbicara dari pra-siklus, ke tindakan siklus 1 dan siklus 2 dengan menggunakan metode mind map terlihat selalu miningkat.

Hal tersebut menunjukkan bahwa penerapan metode mind mapping dapat meningkatkan minat belajar keterampilan berbicara mahasiswa. Belajar menggunakan metode mind map situasi di kelas lebih menyenangkan dan tidak membosankan. Mahasiswa lebih kreatif dan tidak monoton saat berbicara di depan kelas, isi yang dibicarakan lebih bervariasi. Hal tersebut sesuai dengan teori yang dikemukakan oleh Winkel (1996: 212) bahwa minat adalah suatu kecenderungan individu yang menetap, untuk merasa tertarik pada bidang studi 


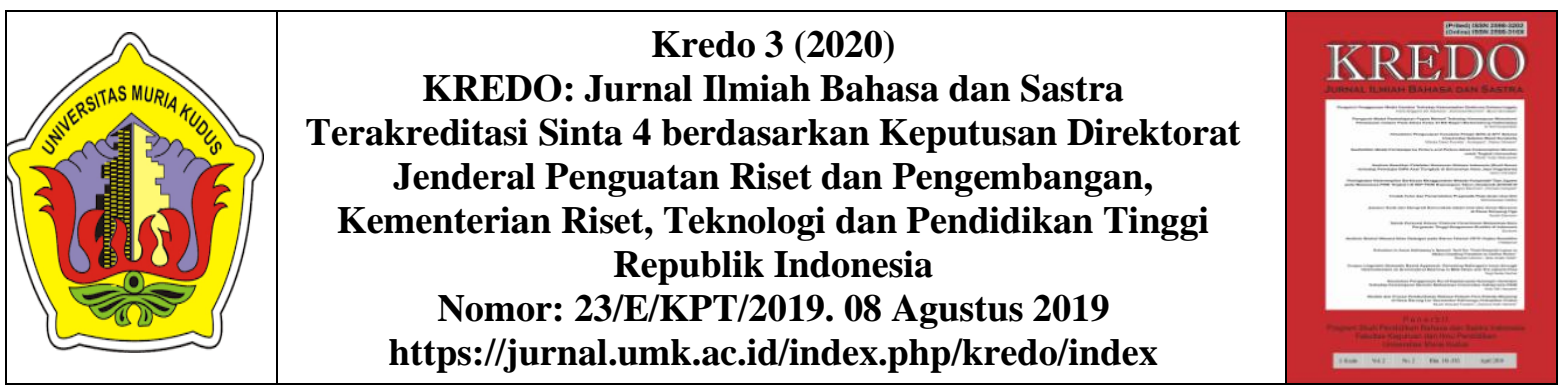

atau pokok bahasan tertentu dan merasa senang mempelajari materi itu. Lebih lanjut, DePorter (2001: 172) bahwa salah satu manfaat mind map yaitu menyenangkan, karena dalam membuat peta pikiran, imajinasi dan kreativitas yang tidak terbatas menjadikan pembuatan serta peninjauan ulang catatan lebih menyenangkan.

Selain itu, hal yang tidak kalah pentingnya adalah kesadaran para mahasiswa akan tanggung jawabnya yakni belajar. Kesadaran ini harus muncul dalam diri setiap pelajar dan harus dilaksanakan dengan sebaikbaiknya. Belajar bukan karena paksaan dari orang tua maupun kewajiban semata, melainkan belajar sudah dirasakan sebagai tanggung jawab bagi setiap mahasiswa. Hal ini terkait dengan minat internal dari mahasiswa untuk belajar. Sejalan dengan itu, Darmuki dan Hidayati (2019:17) mengungkapkan bahwa minat belajar yang tinggi cenderung menghasilkan prestasi belajar yang tinggi. Metode mind map dapat meningkatkan minat belajar mahasiswa, hal ini dapat dilihat dari antusiasme mahasiswa dalam mengikuti pembelajaran. Mahasiswa juga merasakan penggunaan metode mind map menjadikan pembelajaran tidak membosankan dan lebih menyenangkan.

Berdasarkan hasil pengamatan dari pra-siklus, ke pelaksanaan tindakan siklus 1 sampai dengan pelaksanaan tindakan siklus 2 terlihat adanya kenaikan rata-rata nilai mahasiswa baik dari aspek pengetahuan maupun kemampuan mahasiswa dalam pembelajaran keterampilan berbicara. Peningkatan dari pra siklus, siklus 1 dan siklus 2 dapat dilihat pada grafik berikut ini:

270 | Jurnal Kredo

Vol. 3 No. 2 April 2020

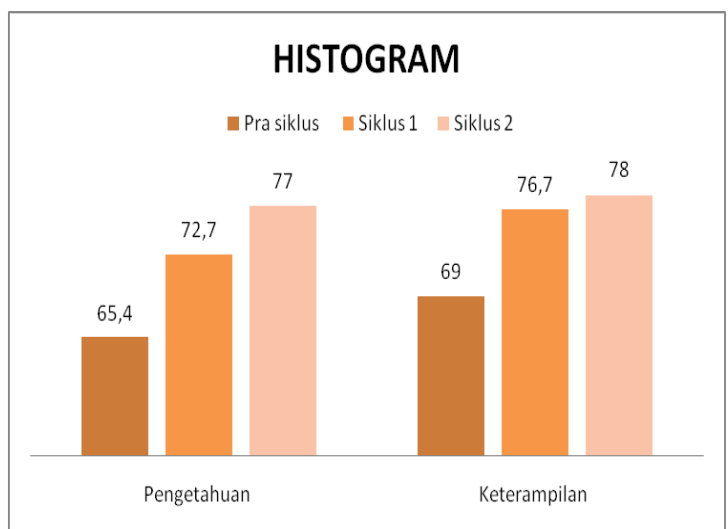

Gambar 1. Grafik Hasil Nilai Mahasiswa

Dilhat secara keseluruhan terdapat peningkatan nilai rata-rata mahasiswa pada pelaksanaan tiap siklus, dilihat dari nilai aspek pengetahuan maupun aspek keterampilan. Terlihat pada grafik bahwa nilai keterampilan lebih tinggi daripada nilai pengetahuan, tetapi pada tahap siklus ke-2 perbedaan itu sudah tidak terlalu besar. Pembelajaran mata kuliah Keterampilan Berbicara menggunakan mind map bukan hanya meningkatkan pengetahuan tetapi juga sekaligus keterampilan mahasiswa. Aspek keterampilan maupun aspek pengetahuan yang meningkat secara umum akan meningkatkan hasil belajar berbicara mahasiswa.

Metode pembelajaran yang digunakan dosen dalam menyampaikan materi pada saat proses belajar mengajar berpengaruh kepada hasil belajar mahasiswa. Hal ini terbukti dengan penggunaan metode mind map yang berhasil meningkatkan kemampuan/keterampilan mahasiswa dalam berbicara (Am adieu, 2009: 385). Hasil pembelajaran juga membuktikan bahwa dari aspek pengetahuan mahasiswa mengalami peningkatan pada siklus 1 dan siklus 2. Hal ini membuktikan bahwa metode mind map dapat meningkatkan hasil belajar mahasiswa dalam mata kuliah 


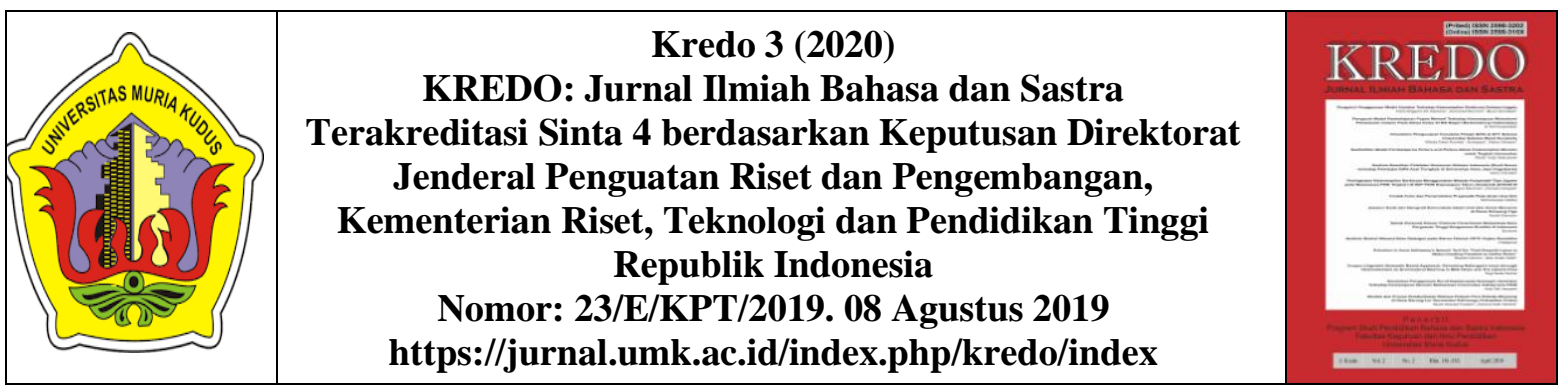

Keterampilan Berbicara. Metode mind map yang digunakan dosen di kelas menjadikan pembelajaran lebih menarik dan tidak membosankan sehingga berdampak pula pada hasil pembelajaran keterampilan berbicara baik dari aspek pengetahuan maupun aspek keterampilan berbicara mahasiswa (Hay et.al., 2008: 310; Davies, 2011: 301). Aspek pengetahuan dan keterampilan mahasiswa meningkat menjadikan mahasiswa alur berbicaranya lebih runtut dan logis sehingga secara kompetensi berbicara mahasiswa lebih kompeten sesuai ketercapaian tujuan pembelajaran.

Berdasarkan data tersebut diketahui bahwa, prestasi belajar mahasiswa dengan penerapan model pembelajaran mind map menunjukkan bahwa kemampuan berbicara meningkat. Dari hasil pembelajaran pra-siklus, siklus 1 sampai dengan siklus 2 yaitu rata-rata nilai pengetahuan pra-siklus sebesar 65,4; siklus 1 memiliki rata-rata sebesar 72,7; dan siklus 2 sebesar 77,0. Sedangkan rata-rata nilai keterampilan yaitu 69,0 pada tahap pra-siklus, 76,2 pada siklus 1 , dan 78,0 pada siklus 2 . Hal ini menjadi bukti bahwa, pemilihan dan penggunaan metode pembelajaran yang tepat dapat meningkatkan prestasi mahasiswa. Hal ini sesuai pendapat De Porter (2001) bahwa metode mind map dapat meningkatkan hasil belajar secara maksimal. Hasil pembelajaran yang meningkat baik dari aspek pengetahuan maupun dari aspek keterampilan menunjukkan bahwa kegiatan pembelajaran menggunakan mind map membantu mahasiswa untuk menguasai keterampilan berbicara sekaligus memiliki pengetahuan berbicara. Penguasaan keterampilan dan pengetahuan berbicara menjadikan mahasiswa lebih runtut berbicara dalam menyampaikan ide, gagasan, pikiran dan informasi kepada orang lain di depan kelas. Mahasiswa ketika berbicara di kelas, alur berpikir mahasiswa lebih runtut dan logis, selain itu kreatifitas penyampaiannya tidak monoton. Secara umum pembelajaran menggunakan metode mind map dapat membuat mahasiswa lebih aktif, kreatif, efektif dan hasil belajar menjadi lebih baik serta maksimal (Ojima, 2006; Pishghadam \& Ghanizadeh, 2006; Quinn et.al., 2006; Rueda dkk., 2009; Williams, 2004).

Berdasarkan hasil siklus 1 dan siklus 2 tersebut, dosen berhasil melaksanakan pembelajaran berbicara dengan metode mind map yang mampu meningkatkan minat dan hasil pembelajaran keterampilan berbicara. Metode mind map juga sebagai sarana bagi dosen untuk membangkitkan minat mahasiswa agar lebih aktif dalam proses pembelajaran berbicara di kelas sehingga pembelajaran lebih menarik dan menyenangkan. Mahasiswa merasa pembelajaran menggunakan mind map lebih menyenangkan dan tidak membosankan, karena mereka bisa belajar dengan kreatif dan tidak monoton. Pembelajaran menggunkan metode mind map secara umum telah berhasil meningkatkan minat dan hasil belajar keterampilan berbicara pada mahasiswa tingkat IA Prodi PBSI IKIP PGRI Bojonegoro Tahun Akademik 2019/2020.

\section{SIMPULAN}

Berdasarkan hasil penelitian di atas penerapan metode mind map pada mahasiswa kelas IA Prodi PBSI IKIP PGRI Bojonegoro dari siklus 1 dan siklus 2 dapat diperoleh simpulan sebagai berikut: (1) Pembelajaran 


Kredo 3 (2020)
KREDO: Jurnal Ilmiah Bahasa dan Sastra
Terakreditasi Sinta 4 berdasarkan Keputusan Direktorat
Jenderal Penguatan Riset dan Pengembangan,
Kementerian Riset, Teknologi dan Pendidikan Tinggi
Republik Indonesia
Nomor: 23/E/KPT/2019. 08 Agustus 2019
https://jurnal.umk.ac.id/index.php/kredo/index

dengan menggunakan metode mind map dapat meningkatkan minat belajar mahasiswa sehingga membuat mahasiswa semakin tertarik dan antusias pada mata kuliah keterampilan berbicara yang terlihat dari hasil angket minat yang meningkat dari pra siklus, siklus 1 ke siklus 2. Hal tersebut dapat dilihat bahwa minat mahasiswa dalam mengikuti pembelajaran berbicara meningkat. Pada siklus 1 sebanyak $60 \%$ (18 orang) dan pada siklus 2 meningkat menjadi $96,7 \%$ (29 orang). ; (2) Pembelajaran dengan mengunakan metode mind map dapat meningkatkan hasil pembelajaran mahasiswa kelas IA Prodi PBSI IKIP PGRI Bojonegoro dalam mata kuliah Keterampilan Berbicara, peningkatan tersebut dari aspek kemampuan maupun pengetahuan mahasiswa. Dari hasil pembelajaran prasiklus, siklus 1 sampai dengan siklus 2 yaitu rata-rata nilai pengetahuan prasiklus sebesar 65,4; siklus 1 memiliki rata-rata sebesar 72,7; dan siklus 2 sebesar 77,0. Sedangkan rata-rata nilai keterampilan yaitu 69,0 pada tahap prasiklus, 76,2 pada siklus 1 , dan 78,0 pada siklus 2 .

\section{DAFTAR PUSTAKA}

Adeneye O. 2011. Effect of Concept Mapping Strategy on Students' Achievement in Junior Secondary School Mathematics. International Journal of Mathematics Trends and Technology, 2(3).11-16.

Ajaja O. Patrick. 2011. Concept Mapping As a Study Skill: Effects on Students Achievement in Biology.Int J Edu Sci, 3(1): 49-57.
Akeju O. O. Simpson, Rotimi C. O \& Kenni A. M. 2012. Teaching With Concept Mapping Instructional Strategy in Nigeria Secondary Schools. Eurasian J. Phys. Chem. Educ., Jan (Special Issue):13-19.

Alireza D. M., Ali Mostafaei \& Davood Ghaderi. 2012. Effects of concept mapping instruction on the academic achievement of students in the history course. Annals of Biological Research, 3 (7):3686-3690.

Am adieu, F., van Gog, T., Paas, F., Tricot, A., \& Marine, C. 2009. Effects of prior knowledge and concept-map structure on disorientation, cognitive load, and learning. Learning and Instruction, 19(5), 376-386.

Arends, R.I. 2008. Learning To Teach (Belajar Untuk Mengajar). Fourth Edition. Boston The McGraw-Hill Company. Inc.

Bamidele, E.F., Oloyede, E. O. 2013. Comparative Effectiveness of Hierarchical, Flowchart and Spider Concept Mapping Strategies on Students' Performance in Chemistry. World Journal of Education. 3(1). 66-76.

Barchok K.H., Too J.K., Ngeno K.J. 2013. Effect of Collaborative Concept Mapping Teaching Strategy on Students' Attitudes Towards Chemistry in Selected Secondary Schools in Kenya. Asian Journal of Social Sciences \& Humanities. 2(2), 530-540. 


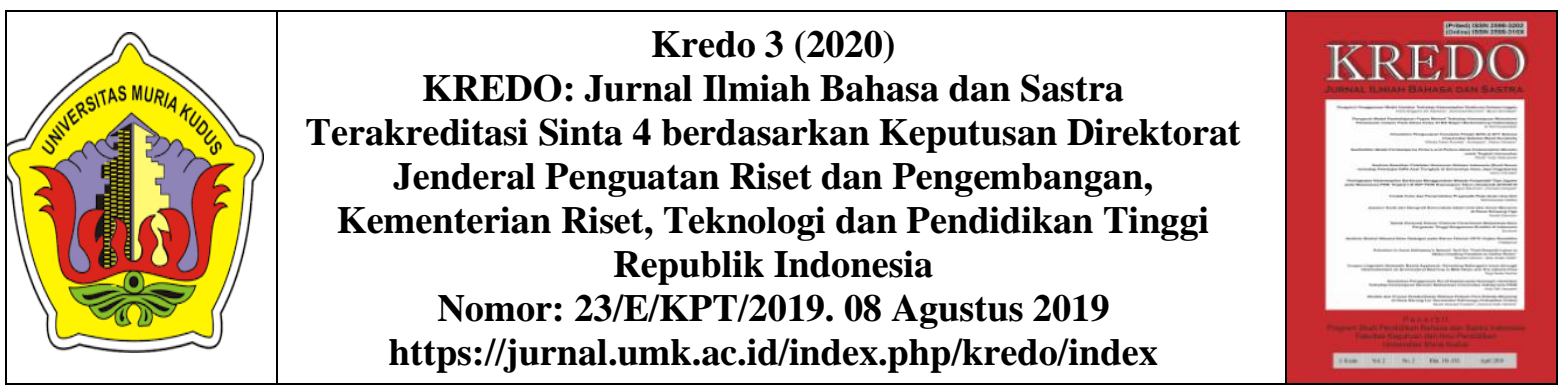

Buzan, T. 2011. Buku Pintar Mind Map. Jakarta: PT. Gramedia Pustaka Utama.

Buzan, Tony and Buzan, B. 1996. The Mind Map Book: How to Use Radiant Thinking to Maximize Your Brain's Untapped Potential. New York: Plume.

Chularut, P., \& DeBacker, T. K. 2004. The influence of concept mapping on achievement, self-regulation, and selfefficacy in students of English as a second language. Contemporary Educational Psychology, 29(3), 248-263.

Cicognani, A. 2000. Concept mapping as a collaborative tool for enhanced online learning. Educational Technology \& Society, 3(3), 150-158.

Darmuki, A. \& Ahmad Hariyadi. 2019. Eksperimentasi Model Pembelajaran Jucama Ditinjau Dari Gaya Belajar Terhadap Prestasi Belajar Mahasiswa Mata Kuliah Berbicara Di Prodi PBSI IKIP PGRI Bojonegoro. Kredo. 3(1), 62-72.

Darmuki, A. \& Hidayati N.A. 2019. An Investigation of The Cooperative Learning Using Audio Visual Media in Speaking Skill Subject. ICSTI. 121-126.

Darmuki, A. \& Hidayati, N.A. 2019. Peningkatan Kemampuan Berbicara Menggunakan Metode Kooperatif Tipe NHT pada Mahasiswa Tingkat I-A Prodi PBSI IKIP PGRI Bojonegoro Tahun
Akademik 2018/2019. Jurnal Pendidikan Edutama. Vol. 6(2), hlm 9-18.

Darmuki, A., Ahmad Hariyadi. 2019.

Peningkatan Keterampilan

Berbicara Menggunakan

Metode Kooperatif Tipe Jigsaw pada Mahasiswa PBSI Tingkat IB IKIP PGRI Bojonegoro Tahun Akademik 2018/2019. Kredo. 2(2), 256-267.

Darmuki, A., Andayani, Joko Nurkamto, Kundharu Saddhono. 2017. Cooperative, Synectics, and CTL Learning Models Toward Speaking Ability Viewd from Students Motivation. Proceeding International Conference on Intellectuals'Global

Responsibility (ASSEHR). Vol. 125, 75-79.

Darmuki, A., Andayani, Joko Nurkamto, Kundharu Saddhono. 2017. Evaluating InformationProcessing-Based Learning Cooperative Model on Speaking Skill Course. Journal of Language Teaching and Reasearch. 8(1) pp. 44-51.

Darmuki, A., Andayani, Joko Nurkamto, Kundharu Saddhono. 2018. The Development and Evaluation of Speaking Learning Model by Cooperative Approach. International Journal of Instruction. 11(2), 115-128.

Darmuki, A., Ahmad Hariyadi, Nur Alfin Hidayati. 2019. Developing Beach Ball Group Investigations Cooperative. International 


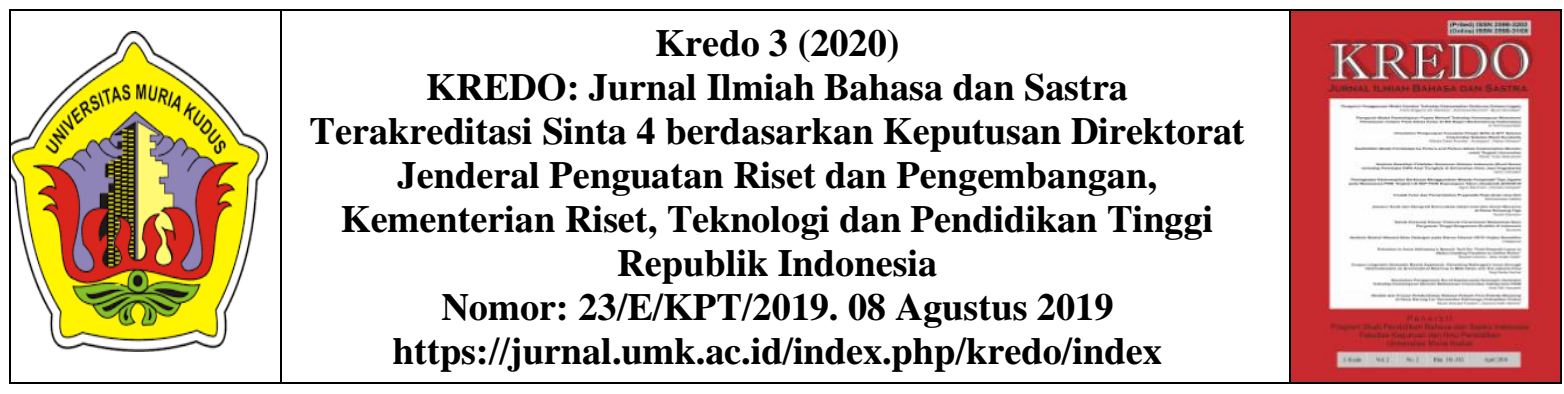

Conferences Seword Fresh, 1-7.

Davies, M. 2011. Concept mapping, mind mapping and argument mapping: what are the differences and do they matter?. Higher Education, 62, 279-301.

De Porter, Bobbi dan Mike Hernacki. 2001. Quantum Learning. Bandung: Mizan Media Utama.

DePorter, Bobbi \& Mike Hernacki. 1999. Quantum Learning Membiasakan Belajar Nyaman dan Menyenangkan. Bandung: Kaifa.

Edward, Caroline. 2009. Mind map untuk anak sehat dan cerdas. Yogyakarta: Sakti.

Eggen, Paul \& Kauchak, Don. 2012. Strategi dan Model Pembelajaran Mengajar Konten dan Keterampilan Berfikir. Jakarta: Indeks.

Fahim, M. \& Heidari, F. 2006. The impact of map training as a postlistening strategy on EFL learners' listening comprehension, ZabanvaAdab, 24, 106-122.

Hsu, C. M., \& Chang, I. H. 2009. The Relationship between Computer-Based Concept Mapping and Creative Performance. Asian Journal of Arts and Sciences, (86), 16-36.

Hwang, G. J., Shi, Y. R., \& Chu, H. C. 2010. A concept map approach to developing collaborative Mindtools for context-aware ubiquitous learning. British Journal of
Educational Technology, 42(5), 778-789.

Gagne, Robert M, dan Briggs, Leslie J. 2005. Principle of Intructional Design. New York: Wardswoth Publishing co.

Hamdani, 2011. Strategi Belajar Mengajar. Bandung: Pustaka Setia.

Hariyadi, A. \& Darmuki, A. 2019. Prestasi dan Motivasi Belajar dengan Konsep Diri. Prosiding Seminar Nasional Penguatan Muatan Lokal Bahasa Daerah sebagai Pondasi Pendidikan Karakter Generasi Milenial. PGSD UMK 2019, 280-286.

Hay, D.B., Kinchin, I., \& Lygo-Baker, S. 2008. Making learning visible: the role of concept mapping in higher education. Studies in Higher Education, 33(3), 295-311.

Hay, D.B. 2008. Developing dialogical concept mapping as elearning technology. British Journal of Educational Technology, 39(6), 10571060.

Kinchin, I. M. 2000. Using concept maps to reveal understanding: a two tier analysis, School Science Review, 81, 41- 46.

Kostovich, C. T., Poradzisz, M., Woood, K., \& O "Brien, K. L. 2007. Learning style preference and student aptitude for concept maps. Journal of Nursing Education, 46(5), 217-224.

Hughes, Arthur. 2003. Testing for Language Teacher. Second 


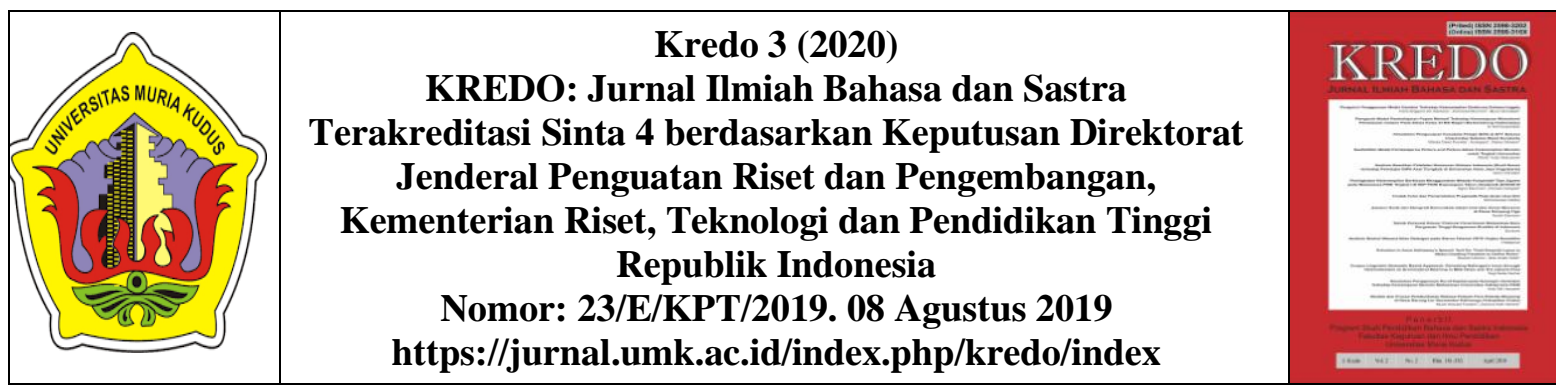

Edition. Cambridge

University Press.

Lim, S.E., Cheng, P.W.C., Lam, M.S. \&

Ngan, S.F. 2003. Developing

Reflective and Thinking

Skills by Means of Semantic

Mapping strategies in

Kindergarten Teacher

Education. Early Child

Development and Care.

172(1):55-72.

Liu, P. 2011. A Study on the Use of

Computerized Concept

Mapping to Assist ESL

Learners' Writing.

Computers \& Education, vol.57(4), pp. 2548-2558.

Marriott, R. and Torres, P. 2008.

'Enhancing Collaborative and Meaningful Language Learning through Concept Mapping'. In A. Okada, S. B. Shum and T. Sherborne (Eds.), knowledge Cartography-Software tools and Mapping Techniques. SpringerVerlag.

Moreira, M. M., \& Moreira, S. M. 2011. Meaningful learning: use of concept maps in foreign language education. Aprendizagem Significativa em Revista/Meaningful Learning Review, V1(2), 6475.

Ojima, M. 2006. Concept mapping as pre-task Planning: A case study of three Japanese ESL Writers. System, 34 (4), 56685.

Peterson, A.R. \& Snyder, P.J. 1998. Using Concept Maps to Teach Social Problems Analysis. Paper presented at the Annual Meeting of the
Society for the Study of Social Problems. Columbus State Community College. San Francisco. 5-28.

Pishghadam, R., \& Ghanizadeh, A. 2006. On the impact of concept mapping as a prewriting activity on EFL learners' writing ability, Iranian Journal of Applied Linguistics, 9, 103-130.

Quinn H.J., Mintzes J.L. \& Laws, R.A. 2004. Successive Conceptmapping. Journal of College Science Teaching 33(3), 1216.

Radix, C., \& Abdool, A. 2013. Using mind maps for the measurement and improvement of learning quality. The Caribbean Teaching Scholar. 3(1), 321.

Rueda, U., Arruarte, A., Elorriaga, J. A., Herran, E. 2009. Learning the attachment Theory with the CM-ED Concept Map Editor. Computers \& Education.52, 460-469.

Şeyihoğlu, A., \& Geçit, Y. 2012. “ Mind Maps " in the Metaphors of Geography Teacher Candidates. International Online Journal of Educational Sciences, 4(2), 283-295.

Sidh, M. S., \& Saleem, N. H. 2013. Interactive Multimedia Cognitive Mind Mapping Approach in Learning Geography. Multimedia Technology. 2(2), 9-17.

Sudjana, Nana. 2005. Dasar-dasar Proses $\backslash$ Belajar Mengajar. 
KREDO: Jurnal Ilmiah Bahasa dan Sastra

Terakreditasi Sinta 4 berdasarkan Keputusan Direktorat

Jenderal Penguatan Riset dan Pengembangan,

Kementerian Riset, Teknologi dan Pendidikan Tinggi

Republik Indonesia

Nomor: 23/E/KPT/2019. 08 Agustus 2019

https://jurnal.umk.ac.id/index.php/kredo/index

Bandung: Sinar Baru Algensindo.

Sutanto, Windura. 2008. Mind Map

Langkah Demi Langkah.

Jakarta: Gramedia.

Sutarni, M. 2011. Penerapan metode mind mapping dalam meningkatkan kemampuan mengerjakan soal cerita bilangan pecahan. Jurnal Pendidikan Penabur. 1(16): 26-33.

Stoica, I., Morarum, S., \& Mironm, C. 2011. Concept maps, a must for the modern teachinglearning process. Romanian Reports in Physics, 63(2), 567-576.

Williams, M. 2004. Concept-mapping - a Strategy for Assessment.
Nursing Standard 10(19),3338.

Winkel, W. S. 1996. Psikologi Pendidikan dan Evaluasi Belajar. Yogyakarta: Gramedia.

Wu, P. H., Hwang, G. J., Milrad, M., Ke, H. R., \& Huang, Y. M. 2012. An innovative concept map approach for improving students" learning performance with an instant feedback mechanism. British Journal of Educational Technology, 43(2), 217-232.

Yen, J. C., Lee, C. Y., \& Chen, I. 2012. The effects of imagebased concept mapping on the learning outcomes and cognitive processes of mobile learners. British Journal of Educational Technology, 43(2), 307-320. 